\title{
Alpine Hydrogeology: The Critical Role of Groundwater in Sourcing the Headwaters of the World
}

\author{
by Masaki Hayashi ${ }^{1,2}$
}

\begin{abstract}
Groundwater discharge in alpine headwaters sustains baseflow in rivers originating in mountain ranges of the world, which is critically important for aquatic habitats, run-of-river hydropower generation, and downstream water supply. Groundwater storage in alpine watersheds was long considered negligible, but recent field-based studies have shown that aquifers are ubiquitous in the alpine zone with no soil and vegetation. Talus, moraine, and rock glacier aquifers are common in many alpine regions of the world, although bedrock aquifers occur in some geological settings. Alpine aquifers consisting of coarse sediments have a fast recession of discharge after the recharge season (e.g., snowmelt) or rainfall events, followed by a slow recession that sustains discharge over a long period. The two-phase recession is likely controlled by the internal structure of the aquifers. Spatial extent and distribution of individual aquifers determine the groundwater storage-discharge characteristics in firstand second-order watersheds in the alpine zone, which in turn govern baseflow characteristics in major rivers. Similar alpine landforms appear to have similar hydrogeological characteristics in many mountain ranges across the world, suggesting that a common conceptual framework can be used to understand alpine aquifers based on geological and geomorphological settings. Such a framework will be useful for parameterizing storage-discharge characteristics in large river hydrological models.
\end{abstract}

\section{Introduction}

Nearly $40 \%$ the world's population depends on rivers originating in high mountains for their water supply (e.g., Viviroli et al. 2019). In temperate climate zones, these rivers typically have a short high-flow period during

\footnotetext{
${ }^{1}$ Corresponding author: Department of Geoscience University of Calgary Alberta Canada; hayashi@ucalgary.ca

${ }^{2}$ Federal Institute for Forest, Snow, and Landscape Research (WSL), Birmensdorf, Switzerland.

Article Impact Statement: This article presents a synthesis of current knowledge on alpine groundwater providing critical baseflow to major rivers of the world.

Received August 2019, accepted November 2019.

(C) 2019 The Author. Groundwater published by Wiley Periodicals, Inc. on behalf of National Ground Water Association.

This is an open access article under the terms of the Creative Commons Attribution-NonCommercial License, which permits use, distribution and reproduction in any medium, provided the original work is properly cited and is not used for commercial purposes.

doi: $10.1111 /$ gwat. 12965
}

spring freshet (e.g., Canadian Cordillera, Paznekas and Hayashi 2016) or monsoon (e.g., Himalayas, Andermann et al. 2012), followed by a long low-flow period sustained by groundwater discharge in headwaters. The amount and timing of high flow have a large interannual variability influenced by the amount of snowpack, the timing of snowmelt, and the amount and timing of summer precipitation. Figure 1a shows an example of the interannual variability for a relatively large $\left(1920 \mathrm{~km}^{2}\right)$ watershed of the North Saskatchewan River in the Canadian Rockies (Paznekas and Hayashi 2016). In contrast, winter low flow is consistent from year to year, indicating substantial groundwater storage in the headwaters of these rivers, sustaining discharge without snowmelt or rainfall recharge, while air temperature remains below $0{ }^{\circ} \mathrm{C}$ and a large amount of snow accumulates (Figure 1b).

In the context of this article, alpine refers to the elevation zone where little or no soil and vegetation are present. In many of large mountain ranges (e.g., European Alps, 
(a)

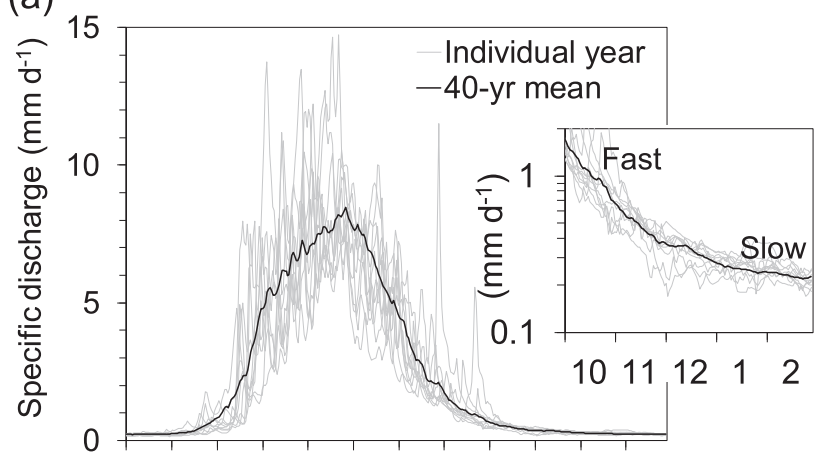

(b)

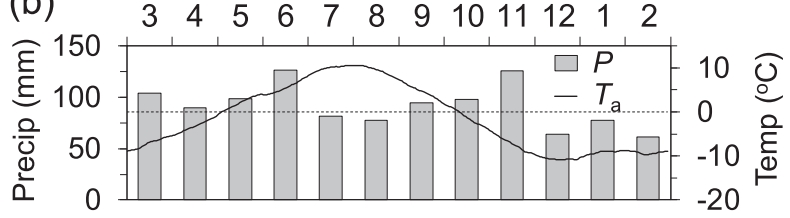

Figure 1. (a) Daily specific discharge hydrograph for the North Saskatchewan River at Whirl Pool Point $\left(5^{\circ}{ }^{\circ} 0^{\prime} 04^{\prime \prime} \mathrm{N}\right.$, $116^{\circ} 28^{\prime} 15^{\prime \prime} \mathrm{W}$ ), starting March 1 and ending February 28 (Government of Canada 2019). Gray lines show individual years during 1971-2010, and the black line shows the 40year mean. The insert shows the two-step recession of lateseason discharge on a logarithmic axis. (b) 2005-2017 mean values of monthly total precipitation $(P)$ and daily mean air temperature $\left(T_{\mathrm{a}}\right)$ observed at a high-elevation $(2230 \mathrm{~m})$ meteorological station in the region (He and Hayashi 2019). A 30-day moving average filter has been applied to $T_{\mathrm{a}}$ to smooth the data.

North American Cordillera, Himalayas), a large fraction of high-elevation watersheds is in the alpine zone (e.g., $66 \%$ for the N. Saskatchewan River). The alpine zone generates a disproportionately large amount of runoff, which is defined as the difference between precipitation and evapotranspiration in the context of this paper. The large alpine runoff is due to high precipitation resulting from orographic effects and low evapotranspiration resulting from sparse vegetative covers (Knowles et al. 2015) and low temperature. Much of the runoff occurs during the high-flow season (Figure 1a), but the stable runoff (i.e., baseflow) during the rest of the year is important for many reasons. For example, it is essential for maintaining critical habitats for aquatic species, sustaining the operation of run-of-river hydropower systems, and providing water supply for downstream communities.

The timing and magnitude of high flows are expected to change as the timing and amount of snowmelt and glacier melt change in response to global warming. For example, the timing of snowmelt-driven discharge will become earlier in temperate regions (Barnett et al. 2005). Aquifers in mountain headwaters may have the capacity to buffer the effects of global warming on the seasonality of river flow by temporarily storing meltwater and releasing it over a long time. However, until recently, we had little understanding of alpine aquifers due to the lack of detailed field-based studies in alpine watersheds with their challenging terrains and severely limited vehicle access.
Over the past two decades, an increasing number of hydrologists have started to pay attention to surface watergroundwater interactions in alpine watersheds and build the library of new knowledge on alpine hydrogeology. It is now possible to identify common types of alpine aquifers and infer their hydrogeological characteristics based on geological and geomorphological settings. The objective of this paper is to present an introduction to alpine hydrogeology by describing the conceptual framework for understanding the function of major aquifer types, discussing the collective behavior of these aquifers at a watershed scale, and suggesting future research directions regarding the integration of field-based knowledge with large-scale river basin hydrology. The focus of this paper is on the hydrogeology of typical alpine landforms such as talus, moraine, rock glacier, and alpine meadow, as they are the most common types of aquifers in the alpine zone. The importance of bedrock aquifers is briefly discussed in the following section. Examples from temperate regions are used to demonstrate the seasonality of hydrology, for example, spring freshet and winter baseflow. While the same seasonality is not applicable to tropical watersheds, the hydrogeological properties of alpine aquifers are expected to be similar in both temperate and tropical regions.

\section{Groundwater Storage in Alpine Watersheds: Sediment and Bedrock}

Alpine zones receive a large amount of precipitation and return a relatively small amount of evapotranspiration to the atmosphere, resulting in a high potential for groundwater recharge (Wilson and Guan 2004). However, it was believed until recently that the high recharge potential was not utilized due to the lack of capacity to store groundwater. Instead, alpine watersheds were considered "Teflon basins" (Clow et al. 2003) consisting mainly of exposed bedrock that provides overland flow to firstorder streams. As a result, the contribution of snow and glacier melt to summer river flow is usually estimated without explicit consideration of groundwater storage and release (e.g., Kaser et al. 2010; Huss 2011). Such estimates may overemphasize direct impacts of global warming on river baseflow by neglecting important functions of groundwater reservoirs in regulating baseflow. In reality steady baseflow during the period of little recharge (e.g., Figure 1a) clearly indicates the presence of alpine aquifers.

Despite the importance of groundwater in mountain headwaters, our understanding of alpine aquifers has been limited, largely due to the difficulty of conducting field-based studies using conventional hydrogeological methods. However, over the past two decades, a small but increasing number of detailed field studies have been conducted in alpine watersheds around the world. These studies have mainly focused on the hydrogeological characteristics of unconsolidated sediments, from which the majority of alpine springs discharge. They commonly occur in typical alpine landforms, such as talus (Caballero 
et al. 2002; Clow et al. 2003; Somers et al. 2016), moraine (Kobierska et al. 2015), and rock glacier (Krainer and Mostler 2002; Winkler et al. 2016).

Recent studies in Switzerland (Floriancic et al. 2018) and China (Chen et al. 2018) have shown that relative amounts of baseflow in alpine streams increase as the percentage of landcover consisting of coarse sediments in the watershed increases, indicating the dominant roles of these sediments in groundwater storage, compared to bedrock (see notable exceptions below). Intensely weathered granitic rocks in mountains can have moderately high porosity and hydraulic conductivity to a substantial depth (Katsuyama and Ohte 2005; Aishlin and McNamara 2011). However, most previous studies on mountain groundwater in weathered bedrock were conducted in subalpine watersheds with soil and vegetation covers. In contrast, exposed bedrock in alpine watersheds tends to have a high erosion rate due to steep slopes (Ballantyne 2002), and as such the development of intensely weathered and fractured zones appears to be limited to a relatively shallow depth $(<10-20 \mathrm{~m})$. It should be noted, however, that important bedrock aquifers do occur in alpine watersheds, for example, karstified carbonate rocks (e.g., Gremaud et al. 2009), evaporites (e.g., Cochand et al. 2019), and highly porous volcanic rocks (e.g., Jefferson et al. 2006). Discussions presented in this article primarily apply to the alpine hydrogeology in non-karstified regions.

The role of high-elevation watersheds in recharging deep groundwater systems, termed mountain block recharge (MBR), has received considerable attention as MBR is seen as an important water input to "basin aquifers" in valley floors (Wilson and Guan 2004; Manning and Solomon 2005; Aishlin and McNamara 2011). Since actual observations of hydraulic head in deep wells drilled in alpine zones are rare (e.g., Manning and Caine 2007), numerical groundwater models were used to evaluate the sensitivity of MBR to topography and bedrock permeability (e.g., Wilson and Guan 2004; Gleeson and Manning 2008). Recent studies have shown that the bedrock groundwater system in high-relief watersheds is topographically driven, with the dominant component being the shallow, local flow system, which discharges to first-order streams (Welch and Allen 2012; Yao et al. 2017; Bresciani et al. 2018). Therefore, the primary role of bedrock recharge seems to be in sustaining the flow in headwater streams, which in turn sustain the flow in higher-order rivers. If a losing-stream condition occurs at the base of the mountain, where the higher-order river encounters a basin aquifer, the river may recharge the aquifer in a process called mountain front recharge (Wilson and Guan 2004).

Bedrock in alpine watersheds typically has low hydraulic conductivity, usually less than $10^{-7} \mathrm{~m} / \mathrm{s}$ (or $0.4 \mathrm{~mm} / \mathrm{h}$ ) even when it is fractured (Wilson and Guan 2004; Welch and Allen 2014). This is lower than typical intensities of spring snowmelt (e.g., Hood and Hayashi 2015) or summer storms, on the order of $1 \mathrm{~mm} / \mathrm{h}$ or higher. Therefore, most of rain and snowmelt water would flow over the exposed bedrock without a mechanism to store water for a sufficiently long time to allow infiltration. The aforementioned alpine landforms provide a potential mechanism to recharge the underlying bedrock in addition to functioning as aquifers themselves (Cochand et al. 2019).

\section{Common Types of Alpine Aquifers}

Alpine zones around the world share common types of landforms consisting of coarse sediments such as talus, moraine, and rock glacier; and alpine meadows formed in depressions or valley floors where fine sediments accumulate. They have substantial capacity to store and transmit groundwater and hence, can be considered alpine aquifers. Depending on geomorphological and geological setting, these aquifers respond differently to hydrological inputs of snowmelt, glacier melt, and rain (Rogger et al. 2017; Glas et al. 2018). The overall groundwater storage-discharge characteristics of alpine watersheds are determined by the size and spatial distribution of individual aquifers.

\section{Talus}

Talus (or scree) is an accumulation of rock debris of various sizes (Figure 2a) transported from a mountain valley wall to a valley floor below by rockfall, avalanche, or alluvial processes (White 1981). The type of transport process influences the composition and internal structure of talus: for example, rockfall talus generally lacks fine sediments, while alluvial talus may have crude bedding structure with layers of fine sediments (e.g., Pierson 1982; Sass 2006). While there are clear examples of talus formed by a single process (White 1981), multiple processes appear to operate in many cases (Davinroy 2000). Talus is a ubiquitous landform in regions influenced by the Pleistocene glaciation (Ballantyne 2002) and covers a sizable fraction of alpine watersheds. As a result, previous studies have reported substantial contribution (up to 70\%) of talus groundwater discharge to total stream flow based on water balance analysis (Davinroy 2000) and chemical and isotopic tracers (Liu et al. 2004; Baraer et al. 2015).

Owing to the dominance of coarse material and a high slope of the underlying bedrock surface, rapid groundwater flow on the order of $10^{-2}$ to $10^{-3} \mathrm{~m} / \mathrm{s}$ has been observed in various studies of talus aquifers (Pierson 1982; Davinroy 2000; Caballero et al. 2002; Clow et al. 2003). Reported examples of hydraulic conductivity range from 0.007 to $0.03 \mathrm{~m} / \mathrm{s}$ (Clow et al. 2003; Muir et al. 2011). However, talus aquifers also have a capacity to store groundwater for a sufficiently long time to allow for rock-water interaction and biogeochemical reactions (Williams et al. 1997; Campbell et al. 2000).

Studies combining hydrological, hydrochemical, and geophysical methods are useful for examining the connection between the internal structure and the hydrogeological characteristics of talus. At the Lake O'Hara watershed in the Canadian Rockies $\left(51^{\circ} 20^{\prime} \mathrm{N}, 116^{\circ} 19^{\prime} \mathrm{W}\right)$, Muir et al. (2011) used electrical resistivity tomography and ground-penetrating radar to image vertical cross 


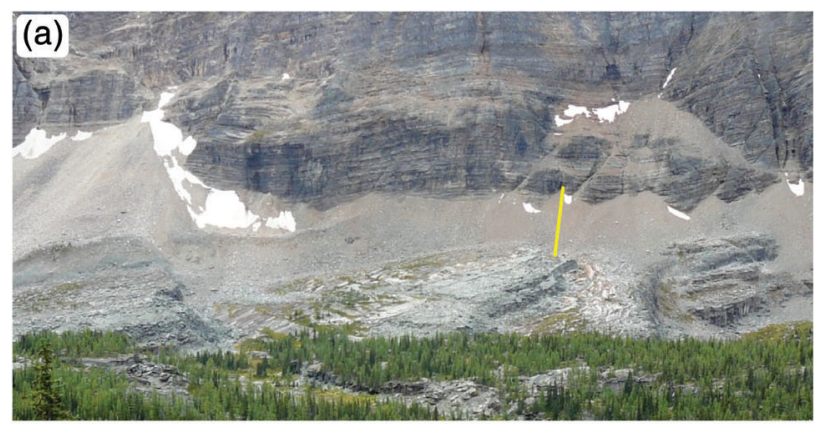

(b)

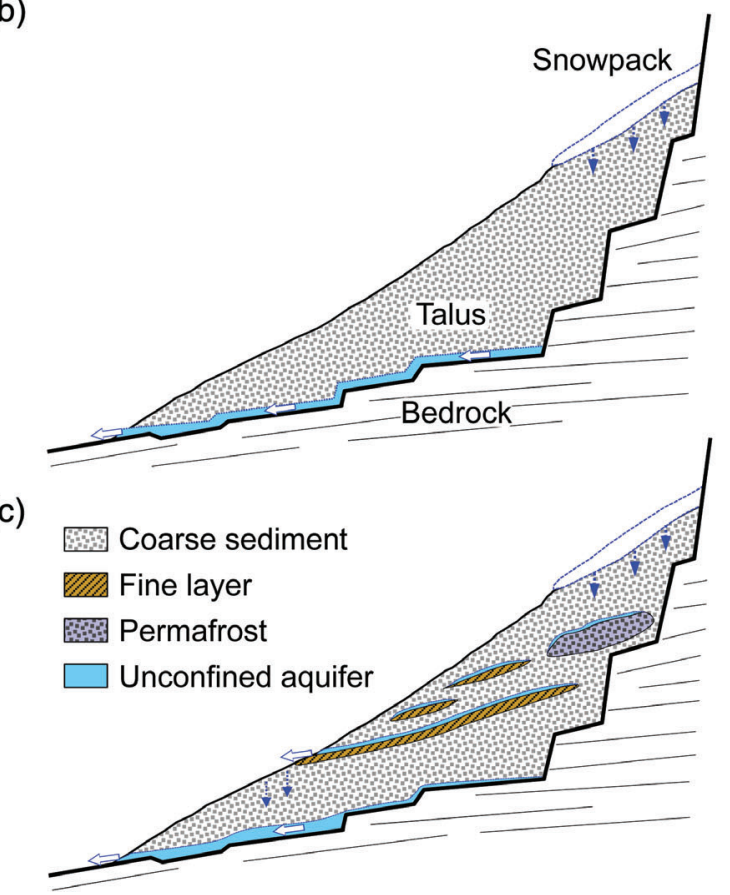

Figure 2. (a) Photograph of the talus studied by Muir et al. (2011) with the yellow line indicating an approximate location of the conceptual model section. (b) Conceptual hydrogeological model of the talus (modified after Muir et al. 2011). (c) Possibilities of internal structures affecting the hydrogeology, whereby permafrost and fine layers provide discontinuous aquitards supporting perched groundwater. Note that this and other diagrams shown in Figures 3-5 are two-dimensional depictions of more complex threedimensional processes.

sections of talus (Figure 2a) mainly consisting of boulders derived from hard quartzite rock. The talus was largely dry except for the top part receiving snowmelt infiltration from the late-lying snowpack, and had a relatively thin $(<0.1 \mathrm{~m})$ saturated layer just above the bedrock surface having a step-like structure (Figure 2b). Despite the high hydraulic conductivity and the small thickness of the saturated layer, the isotopic analysis of groundwater samples from talus-bottom springs showed that the pre-storm water contributed $70-90 \%$ of discharge during summer storm events. This implies a substantial storage capacity in the talus aquifer. Since the exposed bedrock underlying the talus (see Figure 2a) does not have extensive fractures, groundwater storage is likely provided by bedrock depressions similar to those commonly observed in forested hillslopes (e.g., Tromp-van Meerveld and McDonnell 2006), which are filled by fine sediments.

Internal layers of fine sediments in talus were not observed at the Lake O'Hara site, presumably because the hard quartzite does not produce fine sediments as weathering products. In different geological settings, finesediment layers can restrict the vertical infiltration and support multiple saturated zones (Davinroy 2000; Christensen 2017). Nevertheless, conceptual models similar to Figure $2 \mathrm{~b}$ have been reported in the Austrian Alps (Rogger et al. 2017) and the Andes (Caballero et al. 2002; Gordon et al. 2015), and are expected to be applicable to talus in other regions with a modification to include the effects of fine-sediment layers or permafrost (Figure 2c). The main hydrogeological characteristics of talus are: (1) rapid flow through coarse matrix resulting in a fast hydraulic response to snowmelt and rainfall, (2) internal capacity to store water and release it slowly, and (3) a thin saturated zone above the bedrock surface, fine-sediment layers, or permafrost. It is important to note that the total thickness of sediments has little to do with groundwater storage capacity, as the thickness of the saturated zone is small even during snowmelt peaks or summer storms.

\section{Moraine}

Moraine broadly refers to unconsolidated sediments deposited by glaciers. Moraines in alpine watersheds occupy a unique position between glaciers and stream channels, and can modulate the response of streams to inputs of snowmelt, ice melt, and rainfall runoff from glaciers. This is particularly important considering that global warming is causing widespread retreat of alpine glaciers accompanied by expansion of areas covered by proglacial moraine. It should be noted that alpine moraines discussed here exclude ground moraines deposited at the base of glaciers, which are characterized by fine-grained material and some degree of consolidation, resulting in low hydraulic conductivity.

Compared to the vast hydrogeological literature on moraines deposited by the Pleistocene icesheets, few previous workers have studied alpine moraine hydrogeology. Among few hydrological studies of alpine proglacial moraine are observation of groundwater-surface water exchange in moraines in the Peruvian Cordillera Blanca (Gordon et al. 2015; Somers et al. 2016), estimation of hydraulic properties of a glacier forefield in the Swiss Alps (Magnusson et al. 2014; Kobierska et al. 2015), and geophysical investigation of potential groundwater flow pathways in the Austrian Alps (Rogger et al. 2017). These studies have shown that proglacial moraine or till has substantial capacity for transient groundwater storage and contributes significantly to sustain baseflow in streams.

At the Lake O'Hara watershed, a focused hydrogeological study of proglacial moraine was conducted in the sub-watershed of Opabin Creek $\left(4.7 \mathrm{~km}^{2}\right)$, using hydrological, hydrochemical, and geophysical methods (Langston et al. 2011). Similar to numerous glaciated watersheds throughout the world, the Opabin Glacier (Figure 3a) advanced multiple times, with the last two 

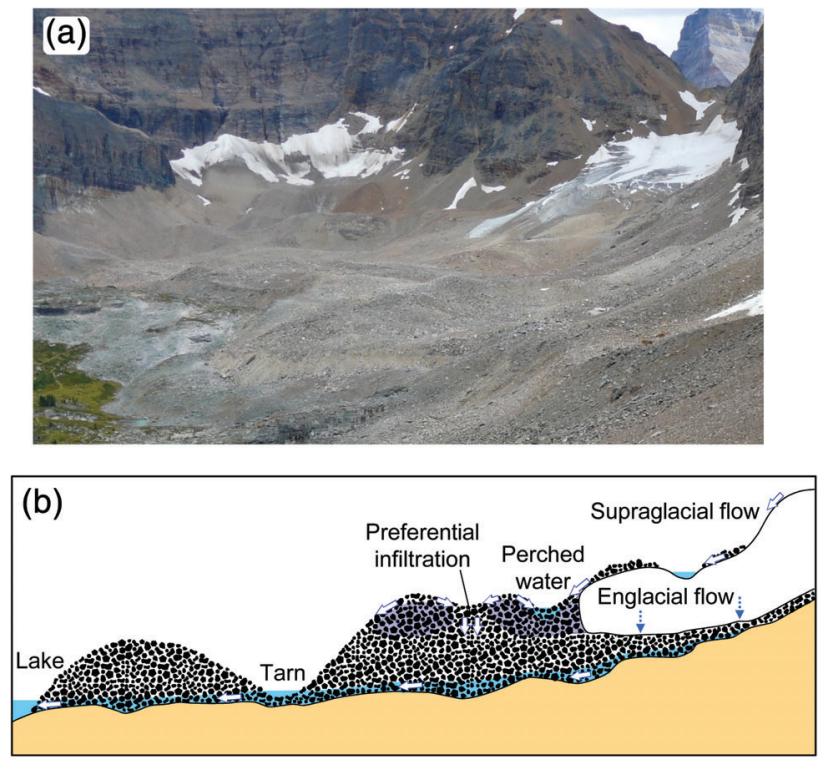

Dry moraine material

Permafrost

Saturated moraine

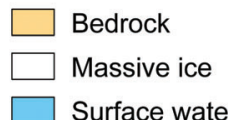

Figure 3. (a) Proglacial moraine and the Opabin Glacier studied by Langston et al. (2011). (b) A conceptual model of the moraine showing major hydrogeological features and flow pathways (modified after Langston et al. 2011). The tarn in the middle of the moraine is considered a surface expression of the water table.

major advances during the Crowfoot period (approximately $11,000 \mathrm{ka}$ ) and the Little Ice Age. The glacier left a thick $(20-30 \mathrm{~m})$ layer of moraine mainly consisting of coarse fragments of quartzite (Figure 3a). Parts of the moraine in shaded areas near the glacier has massive bodies of ice buried under debris cover (i.e., ice-cored permafrost), and other parts have discontinuous ground ice, where ice fills pore spaces between rock fragments (i.e., ice-cemented permafrost) (Figure 3b). This is similar to the Little Ice Age moraine observed in the Austrian Alps (Rogger et al. 2017).

Permafrost is practically impermeable and deflects groundwater flow. As a result, shallow flow paths develop over permafrost and occasionally appear as surface ponding (i.e., tarn) within the moraine (Figure 3b). However, rain and snowmelt water eventually infiltrates through vertical gaps between permafrost bodies and recharges deeper flow paths developed over the sloped bedrock surface. Therefore, the topography of bedrock surface has an important influence on flow paths and discharge locations (McClymont et al. 2012), although some flow may occur through the shallow fractured bedrock zone in some alpine watersheds (see discussion on subsurface flow and storage process below). Deeper flow paths tend to have a longer residence time and greater opportunity to interact with various rock types, potentially resulting in distinctly different chemical signatures of shallow and deep groundwaters converging to outlet spring(s) at the toe of the moraine (Roy and Hayashi
2009). It should be noted that conceptual models shown in Figure $2 \mathrm{~b}$ and Figure $3 \mathrm{~b}$ are two-dimensional depictions of three-dimensional processes controlled by the complex geometry and structure of sediments and underlying bedrock surfaces.

Depending on the bedrock types and the history of glaciation and deglaciation, moraine may consist mainly of coarse rock fragments or contain a large fraction of finer sediments, which affect the hydraulic conductivity. Conductivity data of alpine proglacial moraine are sparse, but the large-scale conductivity of the Opabin moraine is estimated to be on the order of $10^{-3} \mathrm{~m} / \mathrm{s}$ from the water, heat, and mass balance of a tarn (Langston et al. 2013), which is consistent with $4-6 \times 10^{-3} \mathrm{~m} / \mathrm{s}$ reported for coarse-textured till in the Colorado Rockies. In finertextured moraine, the literature suggests conductivity values on the order of $10^{-5}$ to $10^{-4} \mathrm{~m} / \mathrm{s}$ (Magnusson et al. 2014; Rogger et al. 2017; Vincent et al. 2019).

The main hydrogeological characteristics of moraine are: (1) critical position between glaciers and streams allowing it to modulate the timing of glacier melt release to streams, (2) strong effects of bedrock topography and slope, and (3) multiple flow paths influenced by permafrost. Similar to talus, the total thickness of moraine has little to do with groundwater storage capacity, as the thickness of saturated layer(s) is only a small fraction of the total thickness. Thawing of permafrost may have an important influence on groundwater flow paths and storage characteristics (Rogger et al. 2017).

\section{Rock Glacier}

Rock glaciers are ubiquitous in periglacial environments. Different views exist on what should be called a rock glacier, but a morphology-based definition of Berthling (2011) is useful for hydrogeological purposes: rock glacier is the visible expression of cumulative deformation by long-term creep of ice/debris mixtures under permafrost condition. Some rock glaciers originate from debris-covered glaciers, while others originate from mixed accumulation of rockfalls and snow/ice on talus (Jones et al. 2019). Rock glaciers can be divided into three states: active rock glaciers that contain ice and move downslope at a substantial velocity $(0.1-10 \mathrm{~m} /$ year $)$, inactive rock glaciers that contain ice but have stopped moving, and relict rock glaciers that no longer have ice (Winkler et al. 2016).

Active rock glaciers contain largely continuous permafrost and can have multiple sheer zones within (Buchli et al. 2018). Ice contents in active rock glaciers may vary from over $70 \%$ for glacier-derived rock glaciers to $40-70 \%$ for talus-derived rock glaciers (Berthling 2011). In addition to vertical inputs of snowmelt and rain, rock glaciers may receive cascading inputs from talus slopes or glaciers located upslope (Giardino et al. 1992). Due to the low permeability of continuous permafrost, groundwater is forced to flow over the permafrost surface and forms supra-permafrost flow paths with high flow velocity (0.04-0.09 m/s, Tenthorey 1992; Krainer and Mostler 2002). In addition, groundwater may percolate through 
gaps or fractures in permafrost and reach the bottom of the rock glacier and form sub-permafrost flow paths (Jones et al. 2019), which tend to have lower flow velocity (highly variable dependent on material type). Inactive rock glaciers likely have frequent gaps in permafrost, which disrupt supra-permafrost flow paths and enhance the contribution of sub-permafrost flow paths. This is similar to the condition in proglacial moraine containing permafrost, depicted in Figure 3b.

Inactive rock glaciers eventually become relict rock glaciers under a warmer or drier climatic condition, and in some cases become covered by vegetation. Although relict rock glaciers may not be as conspicuous as active ones, they are common features of alpine environments and are expected to have substantial groundwater storage capacity. Among relatively few hydrogeological studies of relict rock glaciers are the studies conducted in the eastern Austrian Alps, where more than 50\% of the area above $2000 \mathrm{~m}$ in elevation is drained through relict rock glaciers or related features (Winkler et al. 2016), implying the important role of relict rock glaciers as the "gate keepers" of alpine headwaters. This study examined a small $\left(0.17 \mathrm{~km}^{2}\right)$ rock glacier using hydrological and geophysical methods and showed that the rock glacier has a two-layer structure with the upper layer conducting fast groundwater flow and the lower layer retaining groundwater and releasing it slowly. They estimated hydraulic conductivity values of $5 \times 10^{-2} \mathrm{~m} / \mathrm{s}$ for the upper layer and $7 \times 10^{-5} \mathrm{~m} / \mathrm{s}$ for the lower layer using artificial tracers.

In another study at the Helen Creek watershed $\left(51^{\circ} 41^{\prime} \mathrm{N}, 116^{\circ} 25^{\prime} \mathrm{W}\right)$ in the Canadian Rockies, Harrington et al. (2018) described the internal structure of an inactive rock glacier containing only a few small blocks of permafrost (Figure 4b). This rock glacier also had fast and slow components. The slow component provided nearly $100 \%$ of the flow in Helen Creek during winter months even though the rock glacier occupied less than $20 \%$ of the watershed. Groundwater discharging from the rock glacier maintained temperature between 0.5 and $2{ }^{\circ} \mathrm{C}$ throughout the year, providing stable-temperature stream habitat for a rare species of trout (Harrington et al. 2017).

The main hydrogeological characteristics of rock glaciers are: (1) presence of supra- and sub-permafrost flow paths for active rock glaciers, (2) potential changes in flow characteristics caused by permafrost thaw, and (3) large groundwater storage capacity of relict rock glaciers as shown by a few available detailed studies. As glaciers are degrading in many mountain ranges, some authors highlighted the significance of permafrost thaw, which could compensate for the loss of glacier melt contribution to streams (e.g., Azócar and Brenning 2010). While this may be the case in exceptional circumstances, the melt rate of permafrost shielded by a debris layer is orders of magnitude lower than the melt rate of exposed glaciers (Arenson and Jakob 2010). Therefore, the primary function of rock glaciers is in the storage of snowmelt and rain, while permafrost controls internal flow
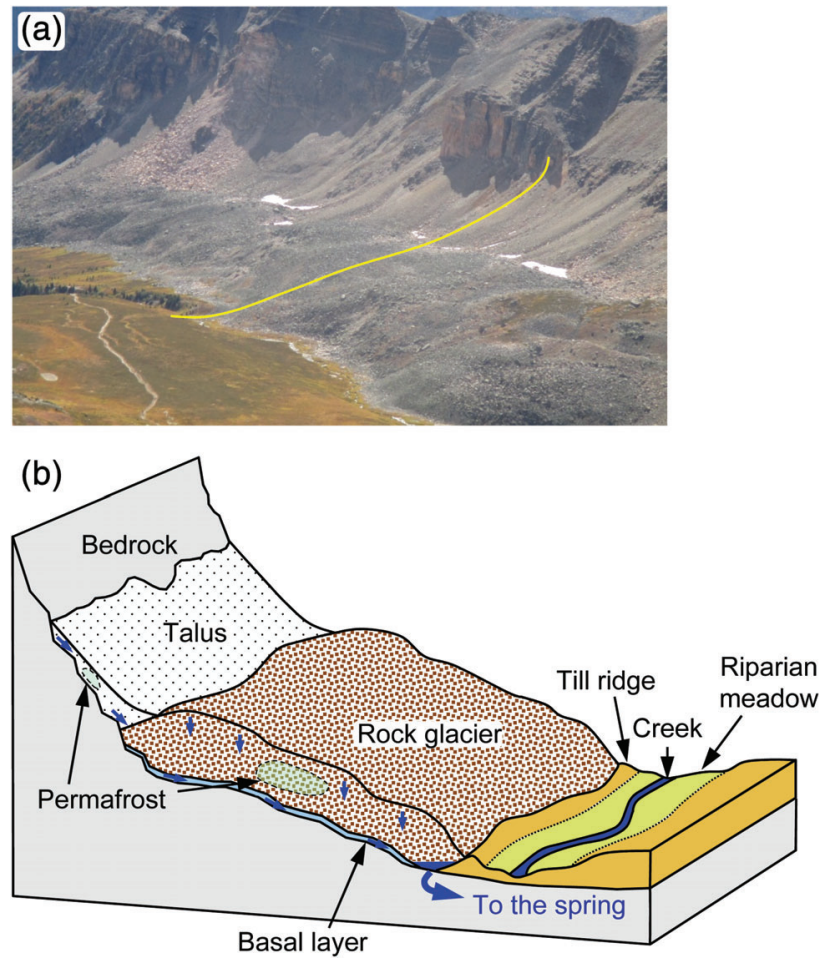

Figure 4. (a) Inactive rock glacier in the Helen Creek watershed. (b) A schematic cross section corresponding to the yellow line in (a). Modified after Harrington et al. (2018).

paths by serving as aquicludes. Permafrost distribution within inactive rock glaciers is influenced by many factors, including local shading, sediment grain size, and groundwater flow, and is an active area of research.

\section{Meadow}

Talus, moraine, and rock glacier consist mainly of coarse sediments with little soil and vegetation covers. These coarse sediments and exposed bedrock cliffs dominate alpine watersheds. In addition, there are some meadows developed in depressions or valleys filled with fine sediments (Figure 5a). These alpine meadows generally maintain soil moisture throughout summer, when precipitation input may be limited, provided by shallow groundwater. For example, in the Lake O'Hara watershed, alpine meadows commonly occur below talus slopes. A detailed geophysical and hydrogeological study of a talus-meadow complex (Figure 5a) showed that the meadow was underlain by a bedrock depression filled by 5-6 $\mathrm{m}$ thick sediments (McClymont et al. 2010). The sill of bedrock at the edge of the depression prevents groundwater from escaping, thus functioning as a subsurface "dam" (Figure 5b). A similar setting was observed in the Sierra Nevada in California by Ciruzzi and Lowry (2017), who demonstrated the importance of buried bedrock ridges under meadow sediments in controlling groundwater storage. At a larger scale, Cochand et al. (2019) showed that meadow sediments deposited in tectonically formed bedrock basins in the Swiss Alps plays an important role in regulating stream flow. 


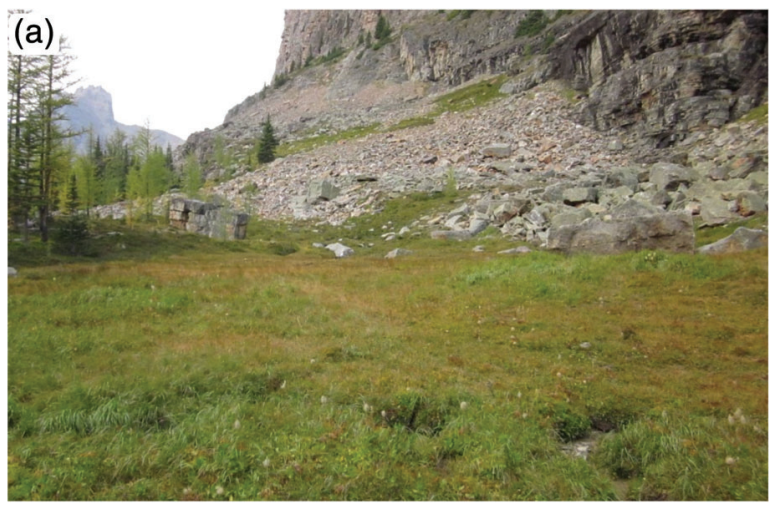

(b)

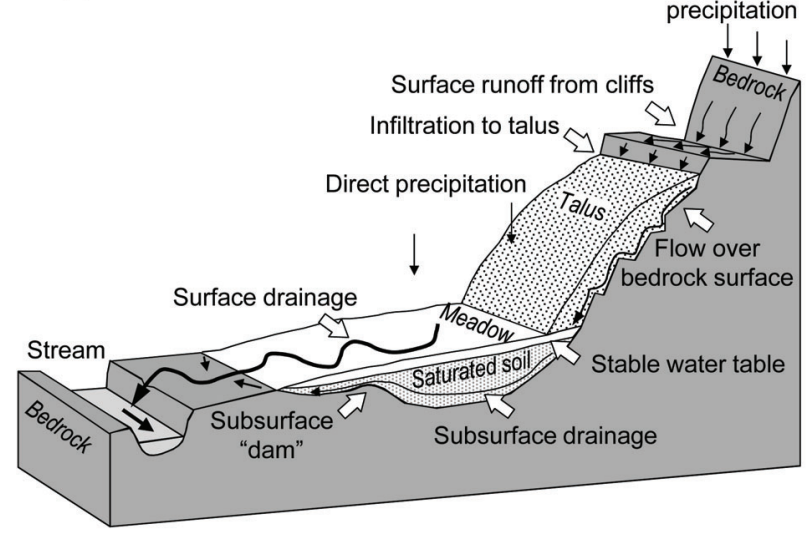

Figure 5. (a) Alpine meadow studied by McClymont et al. (2010). (b) Conceptual model of the hydrogeology of a talus-meadow complex. The talus receives surface runoff derived from late-season snowmelt and precipitation from the bedrock above, as well as direct precipitation. The water infiltrates rapidly through the coarse talus sediments, flows over the bedrock surface, and reaches the meadow. The water table in the meadow is stable, controlled by the subsurface dam provided by the bedrock sill. Modified after McClymont et al. (2010).

Hydrological connections between talus and meadow are commonly observed in alpine regions across the world. For example, in the Peruvian Cordillera Blanca, talus slopes on both sides of glacially formed valleys provide groundwater inputs to valley-sediment aquifers and mid-valley springs (Glas et al. 2018). A similar setting involving talus and a valley-sediment aquifer was observed in the Cordillera Real in Bolivia (Caballero et al. 2002).

The main hydrogeological characteristics of alpine meadows are: (1) relatively thick sediments consisting of both fine and coarse materials, (2) importance of bedrock depressions in storing groundwater and maintaining a shallow water table, thereby sustaining soil moisture in the root zone, and (3) connection with talus and other aquifers providing steady supply of groundwater from upslope areas. Alpine meadows are important ecological niches in fragile alpine environments, which sustain unique alpine flora and fauna. The presence of such flora and fauna depends on perennially moist conditions supported by groundwater.
Other Alpine Hydrogeological Features

In addition to the aforementioned alpine landforms, hydrogeological functions of other landforms have been reported in various mountain ranges. For example, debris fan and cone have functions similar to talus (Clow et al. 2003; Crossman et al. 2011; Gordon et al. 2015). Alluvial fan can interact with talus and moraine to provide additional groundwater storage (Cochand et al. 2019).

Alpine lakes are not aquifers, but they can be a part of groundwater systems through lake-groundwater exchange processes. Many "glacier-fed" lakes are bordered by talus and moraine with no surface water inputs (e.g., Roy and Hayashi 2008). Some lakes have no surface water inflow and outflow and as such, can be considered to be outcrops of the water table (see Figure 3b).

\section{Integrated Aquifer System of Alpine Watersheds}

\section{Upscaling Individual Aquifer Storage \\ to Watershed-Scale Groundwater Storage}

Alpine headwaters contain many aquifer units, and their areal extents and spatial distribution collectively govern the watershed-scale groundwater characteristics. Field-based hydrogeological studies of alpine watersheds are relatively few, but they have shown the importance of the relative positions of aquifers with respect to streams. For example, in a small alpine watershed $\left(6.9 \mathrm{~km}^{2}\right)$ of the Loch Vale underlain by resistant igneous and metamorphic rocks in the Colorado Rockies, Clow et al. (2003) showed that talus plays an important role in receiving water inputs from bedrock cliffs above and storing and transferring groundwater to streams below. Talus springs provide as much as $75 \%$ of stream flow both during storms and baseflow periods. Similarly, in proglacial watersheds in Cordillera Blanca in Peru, talus and debris fan deposits located along valleys receive groundwater recharge and transfer it to aquifers underlying pampas, which is a collective name for clay-rich wet meadows and organic-rich wetlands occurring on the valley floor (Glas et al. 2018). Groundwater discharge from pampa aquifers is critical for sustaining stream flow during dry seasons.

While the aforementioned studies and others have quantified groundwater contribution to stream flow, relating the amount of groundwater discharge to storage at a watershed-scale is challenging as it requires reliable measurements of hydrological inputs and outputs. Accurate measurements of spatially and temporally variable snowmelt fluxes are particularly difficult in remote, highrelief alpine watersheds. Nevertheless, it is important to quantify groundwater storage dynamics and represent them in watershed-scale hydrological models. A few recent studies (see below) have used detailed mapping of snow-cover distributions to estimate spatially distributed transient snowmelt fluxes and determined groundwater storage characteristics in alpine watersheds. 


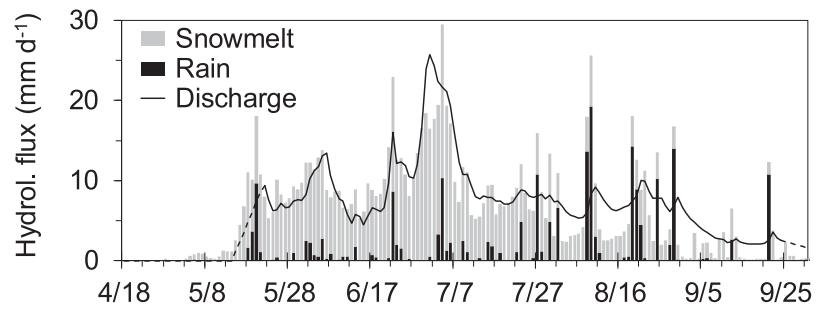

Figure 6. Total daily snowmelt and rainfall inputs and daily stream discharge output at the Opabin watershed in 2008 (modified after Hood and Hayashi 2015). Glacier melt input and evaporation output were negligible compared to the fluxes shown in the graph. Each bar represents the sum of snowmelt and rain.

In the aforementioned Opabin Creek watershed in the Canadian Rockies, Hood and Hayashi (2015) combined snow-depth measurements at 1300 points with a high-resolution remote sensing technique to show that pre-melt snow water equivalent (SWE) had a very high spatial variability $(0-2500 \mathrm{~mm})$, typical of alpine environments, while the watershed-average SWE was $500 \mathrm{~mm}$. The detailed SWE data were used with a physically based snowmelt energy balance model (Tarboton and Luce 1996) to estimate hydrological inputs (snowmelt, precipitation, and glacial melt) and outputs (stream discharge and evaporation). The inputs exceeded the outputs during the melt period, and vice versa in the late season (Figure 6). Using cumulative plots of inputs and outputs, they showed that the maximum amount of groundwater retention was on the order of $70-100 \mathrm{~mm}$. This represents the integrated storage of all aquifers that are annually filled by snowmelt and rain, conceptually similar to the dynamic storage (e.g., Kirchner 2009; Staudinger et al. 2017). The majority (approximately $60 \%$ ) of storage was in moraine, followed by meadow $(15-25 \%)$, lake (10-20\%), and talus (approximately 3\%).

Similar methods were used to estimate seasonal groundwater storage in a $11-\mathrm{km}^{2}$ alpine watershed of Vallon de Réchy in the Swiss Alps (Cochand et al. 2019). The watershed is mostly underlain by quartzite and metamorphic rocks, but an evaporite formation with dolines is exposed at the eastern edge. The estimated seasonal storage was on the order of $300 \mathrm{~mm}$, considerably higher than that of the Opabin watershed above. They showed that springs discharging from the evaporite formation contributed a disproportionately high amount of groundwater, demonstrating the important effects of bedrock geology at this site.

The seasonal (or dynamic) groundwater storage was a small fraction of annual precipitation in both of the well-constrained water balance studies above; $70-100 \mathrm{~mm}$ vs. $1000-1200 \mathrm{~mm}$ in Opabin and $300 \mathrm{~mm}$ vs. $830 \mathrm{~mm}$ in Vallon de Réchy. Considering the high hydraulic conductivity of coarse alpine aquifers located between bedrock cliffs and valleys, the majority of precipitation is expected to infiltrate laterally or vertically into aquifers. Therefore, the figures above suggest that the groundwater retention capacity is much smaller than annual recharge amounts, implying that the hydraulic turnover of groundwater reservoir takes substantially less than a year. However, stable isotope signatures of groundwater in the Opabin watershed clearly indicate that its mean residence time is more than a year (Roy and Hayashi 2009) and that the majority of storm discharge is derived from pre-storm water (Muir et al. 2011). This is consistent with the conclusions of tracer-based studies in other alpine regions (e.g., Baraer et al. 2009; Kobierska et al. 2015). Therefore, alpine aquifer systems have a hydraulically active part of storage having a turnover time on the order of weeks to months, which exchanges water with a less active part having a longer residence time (Ciruzzi and Lowry 2017), as discussed in the following.

\section{Subsurface Flow and Storage Processes}

Talus, moraine, and rock glacier generally consist of coarse sediments having high hydraulic conductivity, resulting in a relatively fast recession of groundwater discharge from these aquifers. However, the fast recession is commonly followed by a slow recession during a long dry or cold season. For example, Figure 7a shows the discharge hydrograph of a spring draining the inactive rock glacier shown in Figure 4 (Harrington et al. 2018). The hydrograph has two distinct phases; a fast recession with an exponential decay coefficient of $0.17 /$ day followed by a slow recession with a decay

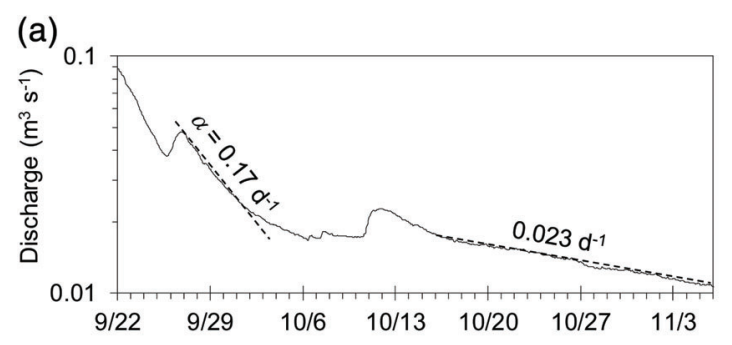

(b)

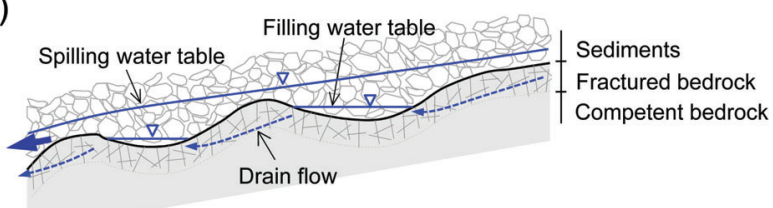

(c)

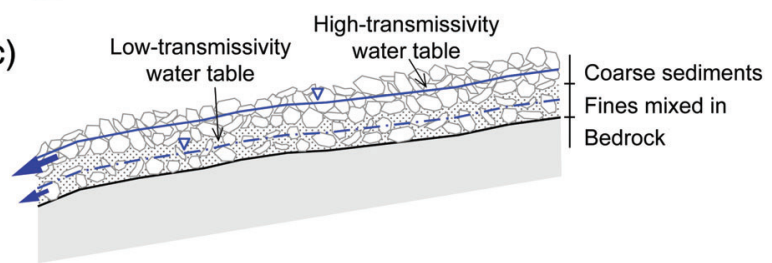

Figure 7. (a) Discharge hydrograph in 2015 of the spring draining the inactive rock glacier shown in Figure 4. Dashed lines indicate the slope $(\alpha)$ of exponential recession. (b) "Fillspill-drain" conceptual model; the dashed blue lines indicate the water table below threshold, while the solid blue line indicates the water table above threshold. (c) "Transmissivity feedback" conceptual model; the dashed blue line indicates the water table in the low hydraulic conductivity zone, while the solid blue line indicates the water table in the high conductivity zone. Modified after Harrington et al. (2018). 


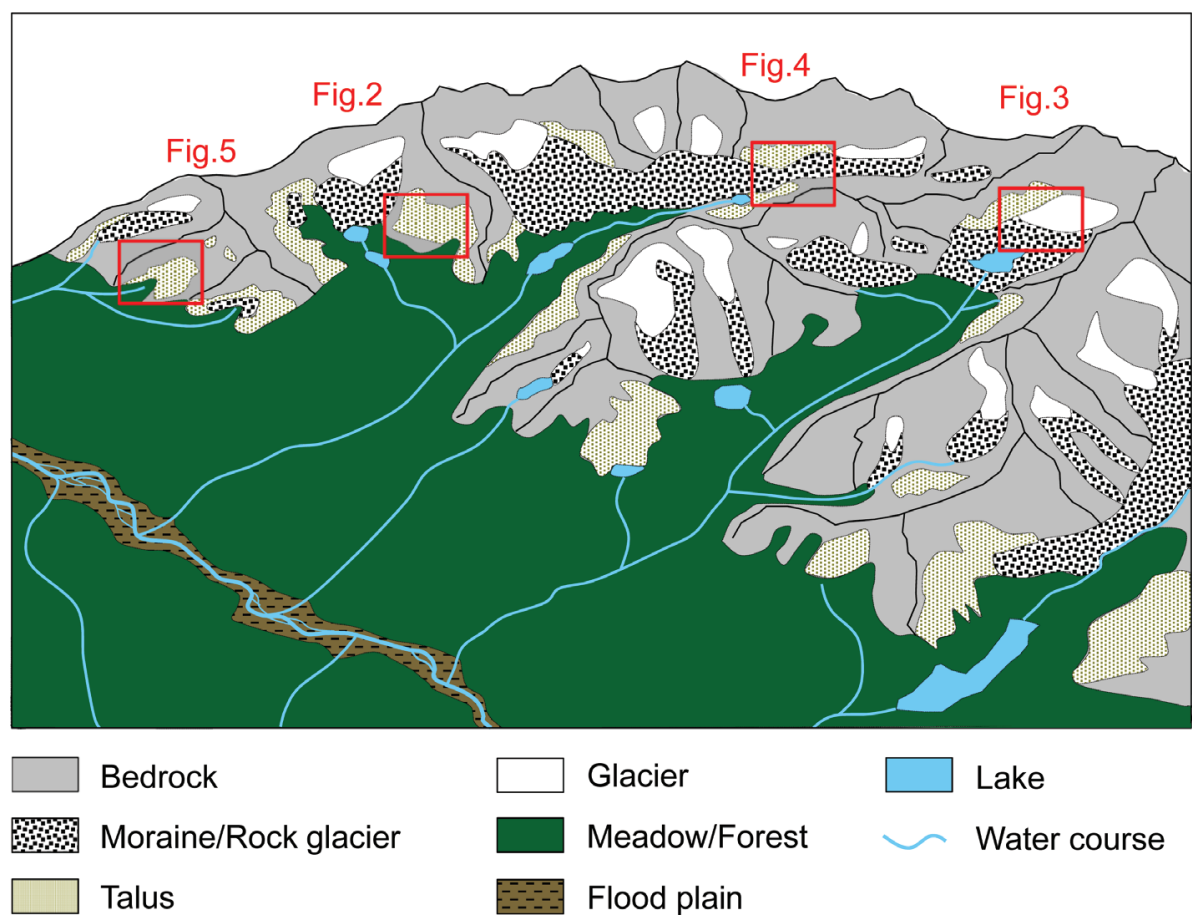

Figure 8. Schematic diagram showing the distribution of alpine aquifers in first- and second-order watersheds feeding a major river. The diagram depicts a typical setting of the Canadian Rockies, where the alpine-subalpine transition occurs at an elevation of $2000-2200 \mathrm{~m}$. Red boxes highlight the hydrogeological settings similar to the conceptual models shown in Figures 2-5. Note that seasonal snow cover is not shown.

coefficient of $0.023 /$ day. Similar, but slower baseflow recession (0.002/day) was observed at the Austrian rock glacier discussed above (Winkler et al. 2016). Two-phase recession is also evident in river discharge hydrographs of larger watersheds having headwaters in the alpine zone (e.g., Figure 1a).

The two-phase recession reflects an underlying mechanism for the retention and slow release of groundwater long after the drainage of the high-conductivity part of the aquifer. Harrington et al. (2018) proposed two possible mechanisms for the two-phase recession of the rock glacier (Figure 7a). Irregular and sloped bedrock topography provides a fill-spill process described in the hillslope hydrology literature (e.g., Tromp-van Meerveld and McDonnell 2006). If the top several meters of bedrock has a dense enough fracture network, groundwater can slowly move from one bedrock depression to another and sustain discharge during the recession by a fill-spilldrain process (Figure 7b). Alternatively, the basal zone of rock glacier (or talus or moraine) may contain fine sediments (Figure 7c). Several processes have been proposed in the literature to explain the placement of basal fine sediments, such as deposition of basal till (e.g., Winkler et al. 2016) or downward transport of fines by infiltrating water (e.g., White 1981). The flow rate decreases as the water table moves down from the high-conductivity to the low-conductivity zone, as described as transmissivity feedback in the hillslope hydrology literature (e.g., Bishop et al. 2011). The actual processes of two-phase recession likely involve a combination of these and other unidentified processes.

\section{Influence on River-Basin Hydrology}

Rivers draining major mountain ranges receive baseflow from their tributaries, which in turn receive baseflow from the first- and second-order streams originating in the alpine zones (Figure 8). The seasonal or dynamic groundwater storage in alpine watersheds is relatively small (on the order of $10^{2} \mathrm{~mm}$ or less) compared to the amount of annual water inputs, but it is sufficiently large for sustaining baseflow on the order of $<1 \mathrm{~mm} \mathrm{~d}^{-1}$ during winter months (see the next section). Basin-scale groundwater storage is determined by the extent, spatial distribution, and connectivity of alpine aquifers (Figure 8).

Coarse sediments of alpine aquifers retain snowmelt and rain, and allow it to recharge fine-grained materials at the base of the aquifers (Figure 7b) or underlying bedrock if it is densely fractured (Figure 7c). Since the thickness of the densely fractured zone conducting groundwater is generally much smaller than the total relief of alpine valleys, fractured-bedrock groundwater is part of the local flow system (Toth 1963) that discharges to first- and second-order streams in steeply incised valleys. The deep flow system directly connecting mountain ridges to large rivers plays a relatively minor role in sustaining baseflow as hydraulic conductivity decrease with depths by orders of magnitude (Welch and Allen 2012; Yao et al. 2017), except for isolated occurrences of discharge, usually in the form of springs from karst (e.g., Gremaud et al. 2009), major faults (e.g., Grasby and Lepitzki 2002), or other high-permeability zones. Therefore, the loworder watersheds depicted in Figure 8 are regarded as 
the elementary blocks, for which groundwater storagedischarge relationship can be constructed and represented in larger-scale hydrological models. The routing of water from low-order watersheds to high-order rivers may occur as groundwater flow through valley-floor aquifers in addition to stream flow. This process needs to be represented in large-scale hydrological models.

\section{Resiliency of Baseflow}

In cold mountainous regions such as the Canadian Cordillera, rainfall and snowmelt are nearly absent for 4-5 months in winter, during which river flow is almost entirely sustained by groundwater discharge (Figure 1). This provides a useful opportunity to examine long-term trends of groundwater discharge in the alpine headwaters of these rivers. Paznekas and Hayashi (2016) examined long-term ( $>25$ years) discharge data in 17 unregulated rivers in the Canadian Cordillera having drainage areas ranging from 250 to $3870 \mathrm{~km}^{2}$. Alpine zones occupy a large fraction $(>40 \%)$ of drainage areas of most of these rivers. Mean air temperature has been rising and glacier coverage has been decreasing in this region (Marshall et al. 2011), implying the possibility of reduction in snowmelt and glacier melt fluxes, and an earlier start and end of the snowmelt recharge period. This could result in reduced baseflow during the late fall and winter. They calculated an average flow in January and February to represent winter flow for each year, and examined statistical trends in winter flow. No decrease in winter flow was observed in any of the 17 rivers suggesting that the alpine headwaters of these rivers have resiliency provided by groundwater storage.

The rivers in the Canadian Cordillera had a remarkably narrow range of long-term mean winter flow (Figure 9), with lower values in drier regions having lower mean annual flow (Paznekas and Hayashi 2016). They used a ratio of mean winter flow to mean annual flow (winter flow index [WFI]) as an indicator of basin-scale groundwater retention capacity. They compared WFI to various attributes of watersheds such as glacier cover, vegetation cover, drainage density, topographic parameters, and bedrock geology. The only significant correlation was found between WFI and geology, more specifically, watersheds underlain by softer Mesozoic sandstone and shale had higher WFI than those underlain by harder Paleozoic quartzite and limestone, indicating the influence of bedrock geology on groundwater retention capacity suggested by earlier studies elsewhere (e.g., Tague and Grant 2009). It is not clear whether this is related to the property of bedrock itself (e.g., fracture density) or to the effects of bedrock types on the extent and composition of weathering products (e.g., boulders vs. fines) forming sedimentary aquifers.

Similar values of WFI are found in high-elevation watersheds of comparable size $\left(250-1380 \mathrm{~km}^{2}\right)$ in the Tianshan Mountains in China (winter flow represented by January-February average) and the Swiss Alps (winter flow represented by the lowest 7-day mean discharge; NM7Q), suggesting that the conceptual framework

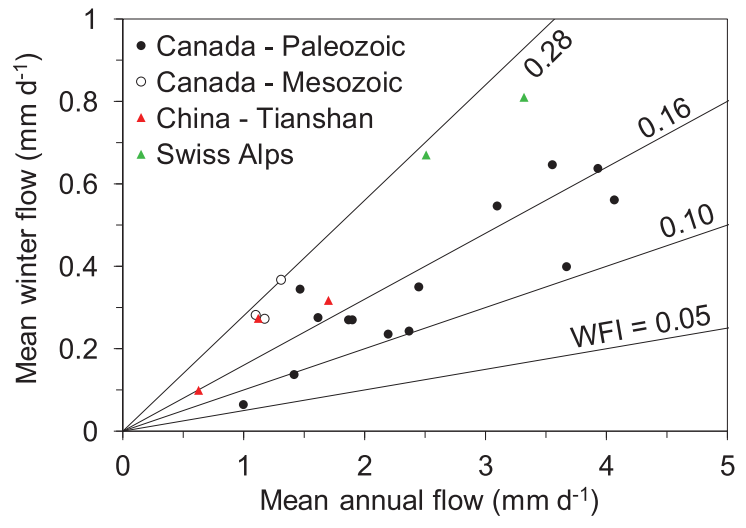

Figure 9. Relation between the long-term mean annual flow and winter flow in high-elevation rivers in temperate regions with drainage areas $>250 \mathrm{~km}^{2}$. Rivers from the Canadian Cordillera (Paznekas and Hayashi 2016) are classified according to the dominant bedrock types; hard Paleozoic quartzite and limestone and soft Mesozoic shale and sandstone. Lines indicate the winter flow index (WFI = winter flow/annual flow). Canadian data are from Paznekas and Hayashi (2016). Chinese data are from the Kalasu, Kamusilang, and Tailan Rivers for 1980-2006 mean values (XDHWR 2007), and Swiss data are from the Kander and Plessur Rivers (Cochand et al. 2019, table S1).

depicted in Figure 8 may be applicable to a broad range of alpine watersheds. Further research is necessary to understand the effects of geology and geomorphology on large-scale groundwater storage-discharge characteristics.

\section{Conclusions}

Alpine headwaters of major rivers have high precipitation due to orographic effects and low evapotranspiration due to the lack of vegetative cover, resulting in high groundwater recharge potential. Recent field-based studies have demonstrated common occurrence of alpine aquifers with large enough capacities to sustain baseflow in first-order streams, and subsequently in major rivers during extended periods of no recharge. Main alpine aquifers consist of coarse surficial sediments such as talus, moraine, and rock glacier. In addition, finer sediments filling bedrock depressions and valley floor store groundwater and provide moisture to alpine vegetation. Depending on geological setting, these aquifers may also provide groundwater recharge to underlying fractured bedrock in some cases. However, due to the reduction of hydraulic conductivity with depth and the high local relief of alpine watersheds, bedrock groundwater forms the shallow, local flow system discharging to first-order streams. Considering the dominant role of surficial aquifers and the local nature of fractured bedrock flow (if it is present), firstorder watersheds are the elementary units for understanding and characterizing alpine hydrogeology.

The groundwater storage-discharge characteristics of first-order watersheds are determined by the spatial extent and distribution of various aquifers (Figure 8). Owing to the high hydraulic conductivity of coarse sediments, these aquifers have fast responses to snowmelt and storm 
events, yet they sustain steady discharge for many months. Chemical and isotopic signatures indicate a long residence time (>1-10 year) of groundwater in these aquifers, suggesting the presence of low-conductivity zones within or under coarse sediments in the form of fine sediments or fractured bedrock.

Small-scale, field-based studies in alpine watersheds have advanced our hydrogeological knowledge and demonstrated common characteristics of alpine aquifers. However, we have not made much progress in linking the small-scale understanding of individual aquifers to watershed-scale hydrogeology, and scaling it up to major river systems. An effective up-scaling approach could use geospatial information such as detailed topography and remotely sensed surficial covers to map the extent and distribution of potential aquifers (Figure 8). Representative storage-discharge characteristics of these aquifers can be inferred from the library of field-based studies and overall geological and geomorphological characteristics of aquifers in a specific region; for example, type of bedrock that generates sediments, and glacial and periglacial processes. Such an approach can be used to estimate watershed-scale storage-discharge characteristics and compare them to observed characteristics to refine the model. Future efforts need to be directed to expanding the library of field-based case studies in different alpine regions of the world, and generalizing and up-scaling the findings of case studies so that storage-discharge characteristics are properly parameterized in large-scale river hydrological models.

\section{Acknowledgments}

This paper is based on the 2018 Henry Darcy Distinguished Lecture organized by the National Groundwater Association. I thank my former and current students, postdoctoral fellows, and research technicians who conducted studies in the Canadian Rockies presented in this paper; and my colleagues who contributed ideas and discussion incorporated into this paper during the Darcy Lecture tour. I also thank Chuntan Han for assistance with Chinese river discharge data, Hye-Seung Jung for assistance with Figure 8, and Garth van der Kamp for insightful comments on an earlier draft. Constructive suggestions by Gerfried Winkler and three anonymous reviewers resulted in improved quality and clarity. The manuscript was prepared when I was on a research fellowship at WSL.

\section{References}

Aishlin, P., and J.P. McNamara. 2011. Bedrock infiltration and mountain block recharge accounting using chloride mass balance. Hydrological Processes 25, no. 12: 1934-1948.

Andermann, C., L. Longuevergne, S. Bonnet, A. Crave, P. Davy, and R. Gloaguen. 2012. Impact of transient groundwater storage on the discharge of Himalayan rivers. Nature Geoscience 5: 127-132.

Arenson, L.U., and M. Jakob. 2010. The significance of rock glaciers in the dry Andes-A discussion of Azócar and Brenning (2010) and Brenning and Azócar (2010). Permafrost and Perigalical Processes 21, no. 3: 282-285.
Azócar, G.F., and A. Brenning. 2010. Hydrological and geomorphological significance of rock glaciers in the dry Andes, Chile $\left(27^{\circ}-33^{\circ} \mathrm{S}\right)$. Permafrost and Periglacial Processes 21, no. 1: 42-53.

Ballantyne, C.K. 2002. Paraglacial geomorphology. Quaternary Science Reviews 21, no. 18-19: 1935-2017.

Baraer, M., J. McKenzie, B.G. Mark, R. Gordon, J. Bury, T. Condom, J. Gomez, S. Knox, and S.K. Fortner. 2015. Contribution of groundwater to the outflow from ungaged glacierized catchments: A multi-site study in the tropical Cordillera Blanca, Peru. Hydrological Processes 29, no. 11: 2561-2581.

Baraer, M., J.M. McKenzie, B.G. Mark, J. Bury, and S. Knox. 2009. Characterizing contributions of glacier melt and groundwater during the dry season in a poorly gauged catchment of the Cordillera Blanca (Peru). Advances in Geosciences 22: 41-49.

Barnett, T.P., J.C. Adam, and D.P. Lettenmaier. 2005. Potential impacts of warming climate on water availability in snowdominated regions. Nature 438: 303-309.

Berthling, I. 2011. Beyond confusion: Rock glaciers as cryoconditional landforms. Geomorphology 131, no. 3-4: 98-106.

Bishop, K., J. Seibert, L. Nyberg, and A. Rodhe. 2011. Water storage in a till catchment. II: Implications of transmissivity feedback for flow paths and turnover times. Hydrological Processes 25, no. 25: 3950-3959.

Bresciani, E., R.H. Cranswick, E.W. Banks, J. Battle-Aguillar, P.G. Cook, and O. Batelaan. 2018. Using hydraulic head, chloride and electrical conductivity data to distinguish between mountain-front and mountain-block recharge to basin aquifers. Hydrology and Earth System Sciences 22, no. 2: 1629-1648.

Buchli, T., A. Kos, P. Limpach, K. Merz, X. Zhou, and S.M. Springman. 2018. Kinematic investigations on the Furggwanghorn Rock Glacier, Switzerland. Permafrost and Periglacial Processes 29, no. 1: 3-20.

Caballero, Y., V. Jomelli, P. Chevallier, and P. Ribstein. 2002. Hydrological characteristics of slope deposits in high tropical mountains (Cordillera Real, Bolivia). Catena 47, no. 2: $101-116$

Campbell, D.H., J.S. Baron, K.A. Tonnessen, P.D. Brooks, and P.F. Schuster. 2000. Controls on nitrogen flux in alpine/subalpine watersheds of Colorado. Water Resources Research 36, no. 1: 37-47.

Chen, R., G. Wang, Y. Yang, J. Liu, C. Han, Y. Song, Z. Liu, and E. Kang. 2018. Effects of cryospheric change on alpine hydrology: Combining a model with observations in the upper reaches of the Hei River, China. Journal of Geophysical Research - Atmospheres 123, no. 7: 3414-3442.

Christensen, C.W. 2017. A geophysical study of alpine groundwater processes and their geologic controls in the southeastern Canadian Rocky Mountains. M.Sc. thesis, University of Calgary, Canada.

Ciruzzi, D.M., and C.S. Lowry. 2017. Impact of complex aquifer geometry on groundwater storage in high-elevation meadows of the Sierra Nevada Mountains, CA. Hydrological Processes 31, no. 10: 1863-1875.

Clow, D.W., L. Schrott, D.H. Campbell, A. Torizzo, and M. Dornblaser. 2003. Ground water occurrence and contributions to streamflow in an alpine catchment, Colorado Front Range. Ground Water 41, no. 7: 937-950.

Cochand, M., P. Christe, P. Ornstein, and D. Hunkeler. 2019. Groundwater storage in high alpine catchments and its contribution to streamflow. Water Resources Research 55, no. 4: 2613-2630.

Crossman, J., C. Bradley, I. Boomer, and A.M. Milner. 2011. Water flow dynamics of groundwater-fed streams and their ecological significance in a glacierized catchment. Arctic, Antarctic, and Alpine Research 43, no. 3: 364-379. 
Davinroy, T. 2000. Hydrologic and biogeochemical characteristics of alpine talus, Colorado Front Range. Ph.D. thesis, University of Colorado, Boulder.

Floriancic, M.G., I. van Meerveld, M. Smoorenburg, M. Margreth, F. Naef, J.W. Kirchner, and P. Molnar. 2018. Spatiotemporal variability in contributions to low flows in the high Alpine Poschiavino catchment. Hydrological Processes 32, no. 26: $3938-3953$.

Giardino, J.R., J.D. Vitek, and J.L. DeMorett. 1992. A model of water movement in rock glaciers and associated water characteristics. In Periglacial Geomorphology, ed. J.C. Dixon, and A.D. Abrahams, 159-184. Chichester, UK: Wiley.

Glas, R., L. Lautz, J. McKenzie, B. Mark, M. Baraer, D. Chavez, and L. Maharaj. 2018. A review of the current state of knowledge of proglacial hydrogeology in the Cordillera Blanca, Peru. WIREs Water 5, no. 5: e1299.

Gleeson, T., and A.H. Manning. 2008. Regional groundwater flow in mountainous terrain: Three-dimensional simulations of topographic and hydrogeologic controls. Water Resources Research 44, no. 10: W10403. https://doi.org/10 .1029/2008WR006848

Gordon, R.P., L.K. Lautz, J.M. McKenzie, B.G. Mark, D. Chavez, and M. Baraer. 2015. Sources and pathways of stream generation in tropical proglacial valleys of the Cordillera Blanca, Peru. Journal of Hydrology 522: $628-644$.

Government of Canada. 2019. Historical hydrometric data, Station 05DA009. https://wateroffice.ec.gc.ca/search/ historical_e.html (accessed July 14, 2019).

Grasby, S.E., and D.A.W. Lepitzki. 2002. Physical and chemical properties of the Sulphur Mountain thermal springs, Banff National Park, and implications for endangered snails. Canadian Journal of Earth Sciences 39, no. 9: 1349-1361.

Gremaud, V., N. Goldscheider, L. Savoy, G. Favre, and H. Masson. 2009. Geological structure, recharge processes and underground drainage of a glacierised karst aquifer system, Tsafleuron-Sanetsch, Swiss Alps. Hydrogeology Journal 17, no. 8: 1833-1848.

Harrington, J.S., A. Mozil, M. Hayashi, and L.R. Bentley. 2018. Groundwater flow and storage processes in an inactive rock glacier. Hydrological Processes 32, no. 20: 3070-3088.

Harrington, J.S., M. Hayashi, and B.L. Kurylyk. 2017. Influence of a rock glacier spring on the stream energy budget and cold-water refuge in an alpine stream. Hydrological Processes 31, no. 26: 4719-4733.

He, J. and M. Hayashi. 2019: LakeO'Hara alpine hydrological observatory: hydrological and meteorological dataset, 2004-2017. Earth System Science Data 11, no.1: 111-117.

Hood, J.L., and M. Hayashi. 2015. Characterization of snowmelt flux and groundwater storage in an alpine headwater basin. Journal of Hydrology 521: 482-497.

Huss, M. 2011. Present and future contribution of glacier storage change to runoff from macroscale drainage basins in Europe. Water Resources Research 47, no. 7: W07511. https://doi.org/10.1029/2010WR010299

Jefferson, A., G. Grant, and T. Rose. 2006. Influence of volcanic history on groundwater patters on the west slope of the Oregon high cascades. Water Resources Research 42, no. 12: W12411. https://doi.org/10.1029/2005WR004812

Jones, D.B., S. Harrison, K. Anderson, and W.B. Whalley. 2019. Rock glaciers and mountain hydrology: A review. EarthScience Reviews 193: 66-90.

Kaser, G., M. Großhauser, and B. Marzeion. 2010. Contribution potential of glaciers to water availability in different climate regimes. Proceedings of the National Academy of Sciences 107, no. 47: 20223-20227.

Katsuyama, M., and N. Ohte. 2005. Effects of bedrock permeability on hillslope and riparian groundwater dynamics in a weathered granite catchment. Water Resources Research 41, no. 1: W01010. https://doi.org/10.1029/2004WR003275
Kirchner, J.W. 2009. Catchments as simple dynamical systems: Catchment characterization, rainfall-runoff modeling, and doing hydrology backward. Water Resources Research 45, no. 2: W02429. https://doi.org/10.1029/2008WR006912

Knowles, J.F., A.A. Harpold, R. Cowie, M. Zeliff, H.R. Barnard, S.P. Burns, P.D. Blanken, J.F. Morse, and M.W. Williams. 2015. The relative contributions of alpine and subalpine ecosystems to the water balance of a mountainous, headwater catchment. Hydrological Processes 29, no. 22: 4794-4808.

Kobierska, F., T. Jonas, J.W. Kirchner, and S.M. Bernasconi. 2015. Linking baseflow separation and groundwater storage dynamics in an alpine basin (Dammagletscher, Switzerland). Hydrology and Earth System Sciences 19, no. 8: 3681-3693.

Krainer, K., and W. Mostler. 2002. Hydrology of active rock glaciers: Examples from Austrian Alps. Arctic, Antarctic, and Alpine Research 34, no. 2: 142-149.

Langston, G., M. Hayashi, and J.W. Roy. 2013. Quantifying groundwater-Surface water interactions in a proglacial moraine using heat and solute tracers. Water Resources Research 49, no. 9: 5411-5426.

Langston, G., L.R. Bentley, M. Hayashi, A.F. McClymont, and A. Pidlisecky. 2011. Internal structure and hydrological functions of an alpine proglacial moraine. Hydrological Processes 25, no. 19: 2967-2982.

Liu, F., M.W. Williams, and N. Caine. 2004. Source waters and flow paths in an alpine catchment, Colorado Front Range, United States. Water Resources Research 40, no. 9: W09401. https://doi.org/10.1029/2004WR003076

Magnusson, J., F. Kobierska, S. Huxol, M. Hayashi, T. Jonas, and J.W. Kirchner. 2014. Melt water driven stream and groundwater stage fluctuations on a glacier forefield (Dammagletscher, Switzerland). Hydrological Processes 28, no. 3: 823-836.

Manning, A.H., and D.K. Solomon. 2005. An integrated environmental tracer approach to characterizing groundwater circulation in a mountain block. Water Resources Research 41, no. 12: W12412.

Manning, A.H. and J.S. Caine. 2007. Groundwaternoble gas, age, and temperature signatures in an Alpine watershed: Valuabletools in conceptual model development. Water Resources Research 43, no.4: W04404, doi:10.1029/2006WR005349.

Marshall, S.J., E.C. White, M.N. Demuth, T. Bolch, R. Wheate, B. Menounos, M. Beedle, and J.M. Shea. 2011. Glacier water resources on the eastern slopes of the Canadian Rocky Mountains. Canadian Water Resources Journal 36, no. 2: $109-134$

McClymont, A.F., M. Hayashi, L.R. Bentley, and J. Liard. 2012. Locating and characterising groundwater storage areas within an alpine watershed using time-lapse gravity, GPR and seismic refraction methods. Hydrological Processes 26, no. 12: $1792-1804$.

McClymont, A.F., M. Hayashi, L.R. Bentley, D. Muir, and E. Ernst. 2010. Groundwater flow and storage within an alpine meadow-talus complex. Hydrology and Earth System Sciences 14, no. 6: 859-872.

Muir, D.L., M. Hayashi, and A.F. McClymont. 2011. Hydrological storage and transmission characteristics of an alpine talus. Hydrological Processes 25, no. 19: 2954-2966.

Paznekas, A., and M. Hayashi. 2016. Groundwater contribution to winter streamflow in the Canadian Rockies. Canadian Water Resources Journal 41, no. 4: 484-499.

Pierson, T.C. 1982. Classification and hydrological characteristics of scree slope deposits in the Northern Craigieburn Range, New Zealand. Journal of Hydrology (New Zealand) 21, no. 1: 34-59.

Rogger, M., G.B. Chirico, H. Hausmann, K. Krainer, E. Brückl, P. Stadler, and G. Blöschl. 2017. Impact of mountain 
permafrost on flow paths and runoff response in a high alpine catchment. Water Resources Research 53, no. 2: $1288-1308$.

Roy, J.W., and M. Hayashi. 2009. Multiple, distinct groundwater flow systems of a single moraine-talus feature in an alpine watershed. Journal of Hydrology 373, no. 1: 139-150.

Roy, J.W., and M. Hayashi. 2008. Groundwater exchange with two small alpine lakes in the Canadian Rockies. Hydrological Processes 22, no. 15: 2838-2846.

Sass, O. 2006. Determination of the internal structure of alpine talus deposits using different geophysical methods (Lechtaler Alps, Austria). Geomorphology 80, no. 1-2: $45-58$.

Somers, L.D., R.P. Gordon, J.M. McKenzie, L.K. Lautz, O. Wigmore, A. Glose, R. Glas, C. Aubry-Wake, B. Mark, M. Baraer, and T. Condom. 2016. Quantifying groundwater-surface interactions in a proglacial valley, Cordillera Blanca, Peru. Hydrological Processes 30, no. 17: 2915-2929.

Staudinger, M., M. Stoelzle, S. Seeger, J. Seibert, M. Weiler, and K. Stahl. 2017. Catchment water storage variation with elevation. Hydrological Processes 31, no. 11: 2000-2015.

Tague, C., and G.E. Grant. 2009. Groundwater dynamics mediate low-flow response to global warming in snow-dominated alpine regions. Water Resources Research 45, no. 7: W07421. https://doi.org/10.1029/2008 WR007179

Tarboton, D.G., and C.H. Luce. 1996. Utah Energy Balance Snow Accumulation and Melt Model (UEB): Computer Model Technical Description and Users Guide. Logan, Utah: Utah Water Research Laboratory.

Tenthorey, G. 1992. Perennial névés and the hydrology of rock glaciers. Permafrost and Periglacial Processes 3, no. 3: 247-252.

Toth, J. 1963. A theoretical analysis of groundwater flow in small drainage basins. Journal of Geophysical Research 68, no. 16: $4795-4812$.

Tromp-van Meerveld, H.J., and J.J. McDonnell. 2006. Threshold relations in subsurface stormflow: 2. The fill and spill hypothesis. Water Resources Research 42, no. 2: W02411. https://doi.org/10.1029/2004WR003800

Vincent, A., S. Violette, and G. Aðalgeirsdóttir. 2019. Groundwater in catchments headed by temperate glaciers: A review. Earth-Science Reviews 188: 59-76.
Viviroli, D., M. Kummu, M. Meybeck, and Y. Wada. 2019. Increasing dependence of lowland population on mountain water resources. EarthArXiv. https://doi.org/10.31223/osf .io/fr5uj

Welch, L.A., and D.M. Allen. 2012. Consistency of groundwater flow patterns in mountainous topography: Implications for valley bottom water replenishment and for defining groundwater flow boundaries. Water Resources Research 48, no. 5: W05526. https://doi.org/10.1029/ 2011WR010901

Welch, L.A. and D.M. Allen. 2014. Hydraulic conductivity characteristics in mountains and implications forconceptualizing bedrock groundwater flow. Hydrogeology Journal 22, no. 5:1003-1026.

White, S.E. 1981. Alpine mass movement forms (noncatastrophic): Classification, description, and significance. Arctic and Alpine Research 13: 127-137.

Williams, M., T. Davinroy, and P.D. Brooks. 1997. Organic and inorganic nitrogen pools in talus fields and subtalus water, Green Lakes Valley, Colorado Front Range. Hydrological Processes 11, no. 13: 1747-1760.

Wilson, J.L., and H. Guan. 2004. Mountain-block hydrology and mountain-front recharge. In Groundwater Recharge in a Desert Environment: The Southwestern United States, ed. J.F. Hogan, F.M. Phillips, and B.R. Scanlon, 113-137. Washington, DC: American Geophysical Union.

Winkler, G., T. Wagner, M. Pauritsch, S. Birk, A. KellererPirklbauer, R. Benischke, A. Leis, R. Morawetz, M.G. Schreilechner, and S. Hergarten. 2016. Identification and assessment of groundwater flow and storage components of the relict Schöneben Rock Glacier, Niedere Tauern Range, Eastern Alps (Austria). Hydrogeology Journal 24, no. 2: 937-953.

Xinjiang Department of Hydrology and Water Resources (XDHWR). 2007. Inland lakes and rivers data, Book 2. In People's Republic of China Hydrology Yearbook. Hydrology Bureau of the Ministry of Water Resources of the People's Republic of China, Beijing.

Yao, Y., C. Zheng, C. Andrews, Y. Zheng, A. Zhang, and J. Liu. 2017. What controls the partitioning between baseflow and mountain block recharge in Qinghai-Tibet Plateau? Geophysical Research Letters 44, no. 16: 8352-8358. 